\title{
Gerakan Teosofi dan Pengaruhnya Terhadap Kaum Priyayi Nasionalis Jawa 1912-1926
}

\author{
Pradipto Niwandhono \\ Staf Pengajar Jurusan Sejarah, Fakultas IImu Budaya, Universitas Airlangga, Surabaya
}

\begin{abstract}
Abstrak
This paper explores the history of the Theosophical Society in colonial Indonesia within the perspective of intellectual history and how it impact the thoughts of Javanese nationalist-aristocrat. The theosophical movement shared the same ideals with Dutch association policy. The main idea is to raise Eastern culture and society to become equals with Western civilisation. The theosophical movement had major contribution in the Javanese cultural revival movement. Many aspect of Theosophy's teachings dealt with Indian esoteric cult, which had a strong impact to the vision of Javanese cultural nationalist: that the ideal Javanese society is no other than ancient Javanese civilisation under Hindu-Buddhist tradition.
\end{abstract}

Kata kunci: Theosophy, Orientalism, Javanese nationalism

\section{Latar Belakang}

Dunia Timur selalu hadir sebagai imajinasi kultural dan intelektual bangsa-bangsa Barat. Sejarah kolonialisme Barat di kepulauan Nusantara selama lebih dari tiga abad lamanya telah diwarnai oleh pertukaran dan kawinsilang (hibridity) kebudayaan serta pemikiran. Salah satu bentuk kawin-silang pemikiran tersebut adalah dalam bidang esoterisme melalui gerakan Teosofi dan organisasi Perkumpulan Teosofi (Theosophical Society) yang menandai zaman baru dalam sejarah esoterisme Barat (lihat Stuckrad, 2005) ${ }^{1}$. Di

1 Sejarah Esoterisme Barat berawal dari upaya mempertemukan filsafat Hellenis, agama-agama misteri di Timur dekat dan tradisi Yahudi-Kristen, dalam suatu gerakan keagamaan yang disebut Gnostisisme (Gnosis $=$ pengetahuan). Aliran ini dianggap sesat (heretis) oleh gereja Katolik pada abad pertengahan, sehingga sempat surut. Masa Renaisans ditandai dengan kebangkitan kembali minat pada ilmu-ilmu esoteris seperti astrologi dan alkimia, dan penerjemahan naskah-naskah filsafat Hermetis. Renaisans dan awal Abad Pencerahan ditandai dengan pelembagaan esoterisme Barat ini kedalam perkumpulan-perkumpulan rahasia (secret society) seperti Rosicrucianisme, Freemasonry, dan berbagai ordo sejenis. kalangan masyarakat pemukim Eropa di Indonesa, gerakan pembebasan pemikiran dan spiritual telah menjadi suatu bidang yang makin diminati oleh para elite kolonial dan menjadi bagian penting dalam perkembangan intelektual mereka. Perkumpulan Teosofi (Theosophical Society) adalah salah satu dari organisasi esoteris yang cukup banyak menggali inspirasi dari ajaran-ajaran kebijaksanaan di dunia Timur.

Sejarah gerakan Teosofi di Indonesia merupakan suatu tema yang masih langka dalam kajian sejarah akademis, mengingat tema ini cukup sensitif dalam wacana keagamaan. Satu masalah penting dalam kajian esoterisme Barat - termasuk Teosofi - adalah tumpang tindihnya muatan faktual sejarah dengan teori persekongkolan (conspiracy theory). Menurut para penganut konspirasi, seluruh sejarah esoterisme Barat dapat dilihat sebagai konspirasi apokaliptik untuk mendirikan suatu agama zaman baru (New Age religion) dan tatanan dunia baru (New 
World Order). Wacana ini diyakini secara luas oleh kaum antisemitis dan kelompokkelompok keagamaan konservatif baik di Barat sendiri maupun di dunia Islam. Keberadaan perkumpuulan-perkumpulan esoteris memang sering dikaitkan dengan konspirasi, dan konspirasi memiliki 'pasar'nya sendiri dalam budaya populer ${ }^{2}$. Meski demikian, dalam satu dekade terakhir esoterisme Barat mulai dimunculkan sebagai objek kajian akademis. Para ahli kajian esoterisme mendirikan berbagai pusat studi, menyelenggarakan seminar internasional dan menerbitakan sejumlah monograf dan buku ${ }^{3}$. Perkembangan ini menginspirasi penulis untuk mengangkat Teosofi di Indonesia dari perspektif sejarah pemikiran, disamping untuk memperluas wacana mengenai esoterisme Barat yang memang masih minim.

Kajian ini memperlihatkan suatu aspek esoterisme Barat yang tidak ada kaitannya dengan "Yahudi", melainkan dengan wacana kolonial tentang "Timur" atau Orientalisme. Menurut penulis, gerakan Teosofi lebih tepat ditafsirkan sebagai bagian dari mentalitas Eropa zaman Romantik, suatu "Orientalisme Romantik" yang memandang Timur dengan pencitraan yang lebih positif bahwa "Timur" adalah bersifat misterius, sensual, mengutamakan keselarasan dengan alam dan nilai-nilai spiritual, berbeda dengan

2 Misalnya dalam novel-novel thriller konspirasi karangan Dan Brown, atau novel satiris Umberto Eco, "Foucault's Pendulum" yang mengisahkan permainan teori konspirasi yang berakibat fatal bagi para pemainnya. Novel ini kaya akan fragmen-fragmen historis dari sejarah esoterisme Barat. Salah satu karya kunci yang mengulas kelompok esoteris sebagai suatu wahana bagi tujuan-tujuan politik tersembunyi ialah Nesta H. Webster, Secret Societies and Subversive Movements (New York : E.P Dutton \& Company, 1924)

3 Tema esoterisme sebagai kajian akademik khususnya sejarah telah dirintis oleh Frances A. Yates dengan karyanya "Giordano Bruno and the Hermetic Tradition" (1968) dan "The Rosicrucian Enlightenment" (1972). Yates berargumen bahwa adanya renaisans filsafat Hermetis pada abad ke-15 dan 17 merupakan faktor utama yang mendukung revolusi sains modern. Kajian ini dikembangkan lebih lanjut oleh para sarjana Eropa antara lain Nicholas Goodrick-Clarke, Antoine Faivre dan Wouter J. Hanegraaff.
"Barat" yang rasional, materialistis dan telah kehilangan kepekaan oleh modernitas dan kapitalisme industrial. Menurut kaum Orientalis romantik semua kualifikasi positif Timur itu telah hilang di masa mereka, sehingga menjadi tugas terhormat bagi Barat untuk memulihkan kembali Timur seperti keadaannya semula dan menemukan kembali "surga yang hilang" dari dunia Timur" (Said,

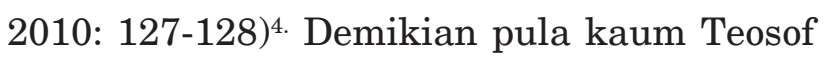
mengklaim gerakan mereka sebagi penemu kembali dan penjaga ancient wisdom dari dunia Timur dari India, Mesir dan pusatpusat kebudayaan kuno yang terlupakan. Di Indonesia, kaum Teosof seperti halnya para orientalis Belanda berkontribusi dalam memunculkan kultus kebudayaan kuno HinduJawa sebagai masa keemasan peradaban Jawa.

\section{Gerakan Teosofi dan Penemuan Kembali Kebijaksanaan Dunia Timur}

Secara etimologi konsep Teosofi berarti "kebijaksanaan ilahi". Teosofi merupakan mazhab esoteris Barat dengan misi untuk melestarikan kebijaksanaan abadi yang menjadi intisari kebenaran religius maupun saintifik dan mewujudkan persaudaraan universal manusia (Nugraha, 2001: 11) ${ }^{5}$. Sebagai organisasi, Perkumpulan Teosofi (Theosophical Society) didirikan tahun 1875 di New York (AS) oleh sekelompok peminat studi okultisme yang dipelopori oleh Helena Petrovna Blavatsky (1831-1891), sorang wanita bangsawan Rusia, dan Henry Steel Olcott (1832-1907), pengacara

4 Sejarah Orientalisme telah berlangsung setua penjelajahan bangsa-bangsa Barat ke dunia Timur sejak Abad Pertengahan, Adapun Orientalisme baru atau "Orientalisme Romantik" bermula dari pembentukan Asiatic Society of Bengal di India oleh Sir William Jones pada 1784, dan Institute de l'Egypte oleh Napoleon Bonaparte dalam ekspedisinya ke Mesir (1798).

5 Tujuan Perkumpulan Teosofi meliputi tiga hal utama : 1) Membentuk inti persaudaraan univeral manusia tanpa membedakan kebangsaan, kepercayaan, kasta maupun warna kulit 2) Mendorong studi komparatif terhadap agama, filsafat dan ilmu pengetahuan 3) Menyelidiki hukum alam dan potensi tersembunyi yang dimiliki manusia dan belum dapat dijelaskan. 
dan veteran perang saudara AS. Pembentukan Perkumpulan Teosofi dilatarbelakangi keprihatinan akan pertentangan agama dan sains pada abad ke-19 khususnya teori evolusi Darwin yang materialistik. Selama berpuluh tahun Blavatsky melakukan studi komparatf terhadap berbagai tradisi keagamaan dan misteri kuno dari berbagai belahan dunia, yang kemudian dituangkannya dalam karyakarya kuncinya, Isis Unveiled (1877) dan The Secret Doctrine (1888). Prinsip dasar dari ajaran Teosofi yang dikemukakan dalam bukubuku tersebut meliputi tiga hal : Pertama, keberadaan suatu Wujud Absolut yang tidak terbatas sekaligus menyatu dengan seluruh gerak kehidupan ; Kedua, periodisitas kosmos atau semesta dalam suatu prinsip siklus; Ketiga, identifikasi seluruh sel kehidupan atau jiwa dengan Jiwa Universal, serta pergerakan seluruh sel kehidupan tersebut melalui siklus inkarnasi (re-inkarnasi). Meski disajikan dalam konsep-konsep filosofis Hinduisme Vedanta dan Buddhisme, kosmologi Blavatsky jelas sekali dipengaruhi oleh prinsip-prinsip Hermetis dan Kabbalistik mengenai identifikasi mikrokosmos-makrokosmos, seperti tersirat dalam pepatah Hermetis "Sebagaimana di atas, demikian pula di bawah" (Goodrick-Clarke, 2008: 223-224).

Dalam sejarahnya, perkumpulan Teosofi telah berkembang menjadi suatu mazhab esoteris yang kompleks dalam berbagai aspek. Ia menyediakan wahana sebagai komunitas intelektual pengkaji okultisme dan perbandingan agama, sekaligus sebagai gerakan kuasi-religius. Perkumpulan Teosofi juga sempat menjadi wadah gerakan politik dan terlibat perselisihan dengan aliranaliran politik lainnya. Perkembangan terakhir ini khususnya berlangsung pada masa kepemimpinan generasi kedua gerakan Teosofi dengan tokohnya Annie Wood Besant (1847-1933) (lihat Hanegraaff: 170-171), ${ }^{6}$ dan

$6 \quad$ Annie Besant ialah seorang wanita Inggris dengan latar belakang keluarga Kristen, dimana suaminya Frank Besant
Charles Webster Leadbeater (1854-1934). Sebagai gerakan kuasi religius, Teosofi memiliki aspek millenarian dan messianistis. Para pendirinya mengklaim bahwa mereka mendapat inspirasi dari para 'master yang tercerahkan' (accesded masters), yaitu orangorang suci yang mengarahkan evolusi spiritual manusia. Juga bahwa sang "Guru Dunia" akan datang kembali dua millenium setelah Kristus. Orang yang akan menjadi inkarnasi selanjutnya adalah Jiddu Krishnamurti (1895-1986). Pemuda belia tersebut kemudian diadopsi oleh Annie Besant, dan dijadikan pelindung dari ordo "Bintang Timur" (Order of the Star in the East), organisasi sayap Teosofi yang dibentuk untuk mempersiapkan kedatangan sang messiah. Peran sebagai mesias masa depan Teosofi ini belakangan ditolak oleh Krishnamurti sendiri pada Agustus 1929, ketika ia menyatakan mundur dari kedudukannya dan membubarkan Ordo Bintang Timur. Krishnamurti menyatakan bahwa tujuannya berada dalam Teosofi bukan untuk mendirikan kultus baru ataupun agama baru, melainkan untuk membebaskan umat manusia (Stuckard, 2005: 132).

Salah satu ciri khas gerakan Teosofi pada masa kepemimpinan Annie Besant adalah aktivitasnya yang cukup besar di bidang politik. Sejarawan Herman A.O de Tollenaere dalam The Poltics of Divine Wisdom : Theosophy and Labour, National and Women Movements in Indonesia ans South Asia 18751947 mengkaji aspek politis Teosofi dibawah kepemimpinan Besant dan hubungannya

adalah seorang pendeta Anglikan. Belakangan ia mulai mempertanyakan kebenaran banyak aspek ajaran Kristen, dan pada usia tigapuluhan semakin cenderung pada atheisme dan pemikiran bebas. Pada tahun 1885, Besant bergabung dengan Fabian Society, suatu perkumpulan buruh berorientasi sosialis. Barulah setelah membaca karya Blavatsky The Secret Doctrine dan menuliskan sebuah review tentangnya, ia berubah haluan dan menjadi seorang Teosof dan salah satu murid kepercayaan Blavatsky pada tahun 1889, hanya dua tahun sebelum pendiri Teosofi ini tutup usia. Besant juga ikut mendirikan perkumpulan CoMasonry, cabang gerakan Freemasonry yang menerima wanita sebagai anggota. 
dengan gerakan buruh sosialis, nasionalisme dan gerakan perempuan (Tollenare, 1996). De Tollenaere menyoroti fenomena yang hampir sejajar dalam kasus perkumpulan Teosofi di Hindia Belanda dibawah kepemimpinan Dirk Van Hinloopen Labberton (menjabat 1912 hingga 1923). Gerakan Teosofi di bawah Annie Besant telah mendukung munculnya kultus kebijaksaan India kuno-khususnya bangsa Arya-yang ternyata membawa pengaruh lebih besar di Eropa. Studinya terhadap Hinduisme dan teks-teks Sanskrit membawa sejumlah hasil diantaranya berupa proyek penerjemahan kitab Bhagavad Gita dengan bantuan seorang sarjana India, Bhagavan Das (Zimmer, 2011: $36-365)^{7}$. Ia juga memprakarsai pembentukan sekolah dan pusat kajian Hinduisme (Central Hindu College). Pada tahun 1916, Besant menjadi pimpinan organisasi Home Rule League dan disusul pada tahun berikutnya, tepatnya Desember 1917, ia menjabat presiden dalam organisasi Kongres Nasional India (Indian National Congress). Popularitas dan pengaruh Annie Besant sebagai aktivis gerakan kemerdekaan mulai surut pada tahun 1920-an dengan munculnya Mahatma Gandhi sebagai tokoh yang menganjurkan perlawanan non-kooperatif terhadap pemerintahan kolonial Inggris.

Kultus terhadap kebijaksanaan India kuno di kalangan Teosofi juga membawa pengaruh di berbagai belahan dunia, tak terkecuali di Indonesia. Seperti kita tinjau dalam bagian berikut, pertumbuhan gerakan Teosofi di Asia berjalan seiring dengan semakin mantapnya wacana kajian ketimuran (orientalis) dari otoritas-otoritas kolonial Eropa di kawasan ini. Ketertarikan Barat terhadap imaji 'Timur yang mistis' telah meningkat khususnya pada masa keemasan Romantisisme di Eropa pada

7 Bhagavad Gita adalah salah satu kitab epos India Kuno yang secara harfiah berarti "nyanyian dewa yang suci" berisi suatu pengkisahan kembali epos Mahabharata dalam bingkai doktrin esoteris Brahmanikal. Kitab ini banyak dijadikan referensi para Teosof. awal abad ke-19 (lihat Clarke, 1997). Gerakan romantik pada dasarnya merupakan antitesis atau reaksi terhadap rasionalitas Pencerahan.. "Penemuan" para Teosof akan India klasik dan ras Arya sebagai akar peradaban Barat yang dilupakan setidaknya telah mendorong gerakan kebangkitan budaya di negara-negara Jermanik. Di Asia Tenggara, khususnya Jawa yang memiliki akar budaya India di masa prakolonial, wacana yang dikembangkan oleh para Teosof dan orientalis Barat juga menyebabkan suatu kultus baru akan kebudayaan JawaIndia di masa lalu yang kemudian dianggap mewakili identitas kebangsaan yang sedang tumbuh di kawasan tersebut.

\section{Van Hinloopen Labberton dan Gerakan Teosofi di Indonesia}

Organisasi Teosofi di Indonesia (Hindia Belanda) pertama kali didirikan pada tahun 1901, dengan dibukanya loge di Semarang yang diresmikan oleh presiden Masyarakat Teosofi Henry Steel Olcott pada tanggal 7 September 1901. Sebelum itu tampaknya sudah terdapat aktivitas Teosofi di Jawa dengan dibukanya loge (loji) di Pekalongan pada tahun 1881 yang dipimpin oleh Baron Van Tengnagel (Nugraha, 2001: 13). Pada bulan April 1912, gerakan Teosofi di Hindia Belanda mencatat suatu tonggak sejarah baru dengan diadakannya Kongres Teosofi bertempat di Loge Betawi Gambir Wetan, Batavia. Kongres tersebut sepakat untuk mendirikan cabang (afdeling) Hindia Belanda yang lepas dari Nederland (Negeri Belanda). Keputusan ini disahkan oleh presiden Masyarakat Teosofi internasional, Annie Besant dan secara resmi berdirilah Nederlandsche-Indische Theosofische Vereeniging (NITV) dengan ketuanya, Dirk van Hinloopen Labberton (Nugraha, 2001: 17).

Perkembangan Teosofi Hindia Belanda setidaknya didukung oleh dua faktor: aktivitas esoterisme Barat dalam masyarakat kolonial, dan kajian-kajian oriental yang dilakukan oleh para ahli etnografi maupun 
agama kolonial. Perkembangan aktivitas kelompok esoteris diwakili oleh organisasi Freemasonry dan berbagai loji Masonik di kota-kota besar Indonesia. Pada akhir abad ke-19, perkumpulan esoteris ini juga berfungsi sebagai wadah bagi aktivitas filantropis dalam mendukung pendidikan dan peningkatan kesejahteraan bagi kaum peranakan Eropa (Indo), yang terdesak oleh meningkatnya pendatang Eropa totok dari Negeri Belanda sejak diberlakukannya kebijaksanaan liberal pada tahun $1870^{8}$. Gagasan persaudaraan universal manusia telah menjadi tema sentral esoterisme Barat dan hal ini membawa dampak dalam pemikiran tentang hubungan kolonial antara para pemukim Eropa dan penduduk asli. Implikasi dari gagasan ini adalah diperkenalkannya politik Etika yang bertujuan mengatasi perbedaan (asosiasi) antara kaum penjajah dan terjajah, dan pada akhirnya modernisasi negara kolonial secara keseluruhan.

Politik Etis ini juga melibatkan kelompok orang-orang Belanda lainnya yang disebut sebagai kaum orientalis, yaitu mereka yang dianggap memiliki wawasan tentang dunia Timur dan kapasitas untuk memutuskan kebijakan kultural yang paling tepat bagi emansipasi kaum pribumi Indonesia. Salah satu tokoh orientalis yang paling penting ialah Christiaan Snouck Hurgronje (1857-1936), seorang pakar studi Islam paling terkemuka pada akhir abad ke-19. Berdasarkan penelitian mendalam terhadap komunitas-komunitas Islam, ia berpendapat bahwa orang Eropa hendaknya membedakan antara Islam sebagai agama dengan Islam sebagai kekuatan politik. Sebagai doktrin religius Islam di Indonesia terbagai dalam sejumlah varian sebagai dampak asimilasi dengan kebudayaan lokal. Akan tetapi

8 Masyarakat Eropa di Hindia Belanda umumnya dibagi menjadi kategori 'trekkers' (perantau atau ekspatriat) yaitu mereka yang tinggal sementara dan kembali saat masa tugasnya selesai dan kaum 'blijvers' atau penetap. Mereka sering juga disebut Indische Nederlander (Belanda Indis) yang terdiri dari kaum Indo-Eropa dan Kreol, yaitu kaum kulit putih kelahiran Hindia. sebagai ideologi, Islam (atau Pan-Islamisme) memiliki potensi besar untuk memobilisasi masyarakat melawan pemerintahan nonMuslim (Samuel, 2010: 21-22) Oleh karena itu pemerintah kolonial perlu terlibat aktif dalam mendukung penguatan identitas lokal dalam menghadapi kemungkinan penyebaran gagasan pan-Islam. Dalam pemikiran kaum orientalis, orang-orang Jawa khususnya kaum priyayi memiliki kedudukan penting, karena mereka merupakan target yang paling mungkin untuk dibentuk menjadi warga Hindia yang termodernisasi atau terbaratkan.

Gagasan asosiasi terutama didukung gerakan Teosofi dengan tokohnya, Dirk van Hinloopen Labberton (1876-1961). Labberton merupakan seorang Teosof Belanda dengan latar belakang yang kuat sebagai orientalis dan dekat dengan dunia Jawa. Ia tiba di Hindia Belanda pada 1894 dan mengawali karirnya di sebuah pabrik gula di Pasuruan, Jawa Timur, serta mulai mempelajari dan mendalami bahasa dan kebudayaan Jawa. Sekitar tahun 1910, Labberton berada di pusat Teosofi di Adyar selama delapan bulan mempelajari bahasa Sanskrit dan ajaran-ajaran esoteris Teosofi. Selama itu Labberton berada dalam bimbingan salah satu tokoh utama Teosofi, C.W. Leadbeater, yang empat tahun kemudian tinggal bersamanya selama berada di Hindia Belanda. Seperti halnya Annie Besant, Labberton tidak dapat memisahkan aktivitas Teosofinya dengan pandangan-pandangan politiknya (Tollenaere, 1996: 113-114).

Karir Labberton yang dekat dengan dunia pendidikan sangat mendukung perannya kemudian dalam mendukung cita-cita asosiasi kaum orientalis dan Etisi Belanda. Antara tahun 1904 hingga 1913, ia diangkat sebagai guru bahasa Jawa pada Gymnasium Koning Willem III, dimana ia berhasil menjalin hubungan akrab dengan siswa-siswa sekolah kedokteran STOVIA. Dengan perannya dalam dunia intelektual Hindia, Labberton menjadi salah satu tokoh yang berpengaruh di kalangan 
elite terpelajar baru di Jawa, khususnya di kalangan priyayi yang terkait dengan Boedi Oetomo (BO). Melalui perantaraan sejumlah anggota $\mathrm{BO}$ yang menaruh minat pada gerakan Teosofi, pengurus perhimpunan Teosofi Hindia mensponsori suatu pertemuan yang dibuka oleh Labberton sendiri pada tanggal 19 Januari 1909, dengan dihadiri sekitar 300 orang. Dalam pidatonya - yang disampaikan dalam bahasa Melayu -- Labberton menyinggung mengenai visi perhimpunan Teosofi terkait dengan 'kebangkitan nasional' Jawa (lihat Nagazumi, 1988: 120-122). ${ }^{9}$ Pandangan dan pemikiran Van Hinloopen Labberton berpengaruh bagi banyak kelompok priyayi Jawa generasi awal pergerakan terutama dalam hal : Pertama, pemikiran mengenai asosiasi yang dibingkai oleh gagasan persaudaraan universal manusia dalam tradisi esoteris Barat, dan Kedua adalah gagasan tentang kewarganegaraan Hindia dalam kampanye "Hindia berketahanan" (Indie Weerbaar) selama masa Perang Dunia pertama.

Gagasan mengenai kewarganegaraan Hindia sangat terkait dengan gagasan tentang nasion Hindia yang mencakup semua orang yang lahir dan menetap di Hindia Belanda tanpa membedakan kategori rasial dan etnisnya. Meski demikian Labberton menolak ide nasionalisme Hindia ala Douwes Dekker yang memperjuangkan kemerdekaan penuh Hindia dari ikatan kolonial dengan kerajaan Belanda (lihat Niwandhono, 2011) ${ }^{10}$. Kepada tiga tokoh Indische Partij Labberton menulis surat terbuka dalam jurnal Theosofisch Mandblad voor Nederlandsch Indie pada tanggal 6 September 1913:

9 Pidato sambutan Hinloopen Labberton kemudian dibukukan dengan judul "Theosophie untuk Boedi Oetomo".

10 Nasionalime Hindia atau Indisch berasal dari gerakan emansipasi kaum Indo-Eropa dengan organisasiorganisasinya seperti Indische Bond (1898), Insulinde (1907) dan khususnya Indische Partij. Mula-mula mereka memperjuangkan kepentingan golongan Indis Belanda baik peranakan (Indo) maupun kulit putih kelahiran Hindia (Kreol) - dalam menghadapi dominasi kaum pendatang (trekkers). Douwes Dekker memperluas pengertian nasion 'Hindia' (Indis) sebagai semua penduduk yang lahir dan menetap di Hindia Belanda.
"Kalian mencintai kebebasan, tetapi sudahkah kalian pikirkan apakah kebebasan sejati itu ? Sebaiknya kalian tahu bahwa kebebasan sejati hanya ada ketika manusia menyadari batas-batasnya. Akankah kalian ambil seekor burung kecil yang masih belajar terbang dari sarangnya, yang meski memenjarakannya di atas dahan, tetapi juga menyelamatkannya dari celaka karena terjatuh...Jawa dan Belanda semestinya bersatu..bukan dengan kekuatan melainkan hanya dengan Kebijaksanaan dan Kasih, kita dapat menemukan kemajuan sejati" (Tollenaere, 1996: 300-301).

Hubungan gerakan Teosofi dengan nasionalisme Hindia menyimpan ambivalensi. Kita dapat melihat bagaimana gagasan tokoh-tokoh Indo-Eropa dalam IP mengenai asimilasi kaum Indo dalam masyarakat Hindia yang multi-etnis merupakan suatu ide yang mungkin untuk terpikirkan dan terwujud dalam kerangka gagasan besar "asosiasi" kaum Etisi atau Orientalis Belanda. Meski demikian jelas bahwa gagasan asosiatif yang dimaksud merupakan suatu rancangan yang dimaksudkan untuk memperkuat ikatan kultural dan intelektual antara koloni dan kerajaan Belanda, bukan sebaliknya. Pendukung gagasan kaum Teosof yang paling utama sebenarnya adalah kaum priyayi generasi baru pendukung kebangkitan kembali budaya Jawa, termasuk juga sebagian pryayi baru yang menempuh pendidikan di Negeri Belanda.

\section{Pengaruh Teosofi dalam Pemikiran Nasionalisme Jawa}

Kelahiran Boedi Oetomo menandai tahapan atau periode pertama dari dua tahapan sejarah gerakan nasionalis di Indonesia. Tahapan pertama yang dimaksud adalah tahap 'asosiasi' antara tahun 1908 hingga 1926 dimana pada periode ini ditandai dengan proses penyerapan gagasan-gagasan Barat dalam dunia pergerakan Indonesia yang kemudian melahirkan gagasan kebangsaaan Indonesia. 
Pada waktu itu wacana yang dominan adalah 'emansipasi' penduduk Hindia agar mencapai taraf kehidupan yang sejajar dengan orangorang Eropa, dan suatu saat dapat mencapai kemandirian politik. Periode ini juga ditandai dengan munculnya partai-partai 'asosiasi' atau partai dengan keanggotaan campuran baik dari golongan bangsa Eropa maupun pribumi. Partai ini mencerminkan gagasan asosiasi atau penyatuan bangsa Eropa dan Asia dalam kedudukan sama sebagai warga Hindia Belanda (lihat Bosma, 2004) ${ }^{11}$.Tahapan kedua merupakan tahap "polarisasi" dimana masa ini merupakan masa perkembangan "nasionalisme yang sesungguhnya" yaitu antara tahun 1926 hingga 1942. Adanya pemberontakan kaum komunis telah menyebabkan perubahan drastis dalam politik negara kolonial berupa ditinggalkannya politik Etika dan dimulainya kebijakan represif terhadap kaum pergerakan. Polarisasi ditandai dengan banyaknya orang Indonesia yang keluar dari perkumpulanperkumpulan asosiasi dan memilih bergabung dengan organisasi-organisasi Indonesia asli. Sementara kecenderungan rasisme juga meningkat di kalangan orang-orang Eropa, ditandai dengan penolakan oleh orang-orang Belanda dan Indo di Volksraad terhadap ususlan untuk diwakilinya mayoritas bumiputra (Nugraha, 2001: 127-128).

Dalam periode asosiasi tersebut telah muncul pemikiran mengenai nasionalisme Jawa dan kebangkitan ("renaisans") budaya Jawa. Aliran pemikiran ini muncul di kalangan elite baru priyayi Jawa yang sebagian besar berafiliasi dengan gerakan Teosofi, dan diwakili

11 Di antara partai-partai asosiasi yang berhaluan paling radikal adalah Indische Partij (IP) yang didirikan pada tahun 1912 oleh seorang jurnalis Indo-Eropa bernama Ernest Francois Eugene Douwes Dekker, bersama sekelompok priyayi Jawa berfikiran modernis. Partai ini menuntut lepasnya Hindia dari Kerajaan Belanda sehingga dilarang oleh pemerintah. Wacana tentang peleburan golongan Eropa dan Indo-Eropa kelahiran Hindia (golongan Indisch) ke dalam kebangsaan Hindia berasal dari kelompok Indo-Eropa pengikut Douwes Dekker. Pemikiran ini menjadi inspirasi bagi gerakan hak sipil Hindia yang melahirkan Volksraad. oleh organisasi-organisasi Boedi Oetomo (1908), Tri Koro Dharmo (1915) dan Jong Java (1918). Pemikiran generasi pertama kaum priyayi baru ini meliputi beragam varian dari yang cenderung tradisionalis, moderat hingga kaum modernis-radikal. Kelompok tradisionalis meliputi sebagian besar generasi tua dalam Boedi Oetomo maupun sebagian kelompok muda. Di antara ketiga aliran itu, kaum tradisionalis pada adalah pendukung utama gagasan bangsa (nasion) Jawa dengan argumen bahwa sebelum datangnya zaman penjajahan Barat, Jawa pernah mencapai tingkat peradaban tinggi. Menurut Hans Van Miert, kecenderungan nasionalisme Jawa ini diperkuat oleh sejumlah faktor seperti perkembangan pengetahuan tentang Jawa kuno khususnya Majapahit oleh kajian-kajian orientalis Belanda, dan munculnya konsep nasionalisme tandingan yaitu konsep tentang nasion Hindia dari Indische Partij (Miert, 2003: 117).

Salah satu tokoh utama dari aliran ini adalah R.M. Soetatmo Soeriokoesoemo (1888-1924), seorang priyayi dari dinasti Paku Alaman dan sepupu dari Soewardi Soerjaningrat atau Ki Hadjar Dewantara. Soetatmo adalah seorang bangsawan yang tertarik pada aktivitas kebatinan atau mistisisme, dan bersama Soewardi ia menjadi anggota kelompok mistik Jawa, Selasa Kliwon yang dipimpin mistikus Jawa terkenal, Ki Ageng Soerjomentaram. Karir politik Soetatmo dimulai sejak ia menjadi anggota Indische Partij pada tahun 1912, dan bersama Soewardi Soerjaningrat ia juga ikut terlibat dalam pembentukan Comite Boemipoetra atau "Komite untuk memperingati seratus tahun kemerdekaan Belanda”. Organisaasi ini segera dilarang setelah penerbitan artikel oleh Soewardi dengan judul Als Ik Eens Nederlander was ("andaikan aku seorang Belanda") yang mengkritik perayaan tersebut dan meyebabkannya diasingkan ke Negeri Belanda. Soetatmo Soeriokoesoemo kemudian 
mendekati Boedi Oetomo dan sekitar tahun 1916 ia menjadi anggota pengurus besar BO. Pada tahun 1921, ia masuk sebagai anggota Volksraad mewakili BO, sebelum akhirnya bergabung bersama Soewardi mendirikan perguruan Taman Siswa (Miert, 2003: 122123).

Soetatmo adalah contoh khas dari nasionalisme Jawa. Ia mengidealisasikan suatu negara otokratis yang merupakan penjelmaan kembali tatanan politik Jawa pra-kolonial. Soetatmo sama-sama menolak baik pemikiran nasionalisme multi-etnik Hindia, demokrasi liberal Barat, Islamisme maupun Marxisme. Lawan utama dari pemikiran Soetatmo adalah Tjipto Mangoenkoesoemo (Sularto, ed., 2001), seorang priyayi berhaluan modernis dan anti-feodal. Berbagai gagasan Soetatmo mengenai spiritualitas bagaimanapun lebih berakar pada tafsiran para Teosof Eropa mengenai agama-agama India, khususnya sistem masyarakat berkasta ala India. Seperti juga kebanyakan Teosof ia memandang perlunya mempertahankan tatanan hierarkis masyarakat, dan menyamakan kaum Marxis maupun mereka yang mendukung demokrasi liberal sebagai "kaum sudra" yang tidak mampu menyerap ajaran-ajaran kearifan dari para orang bijak di atas mereka ${ }^{12}$.

Pada tahun 1917, di bawah pengaruh Soetatmo Soeriokoesoemo didirikanlah Comite voor het Javaans Nationalisme (Komite Untuk Nasionalisme Jawa) dengan organ majalahnya diberi tajuk "Wederopbouw" ("Kebangunan kembali”). Sebagian besar eksponen organisasi ini terkait dengan gerakan Teosofi. Menurut mereka kebudayaan Jawa yang penah mendapat posisi terhormat di Asia Tenggara harus dipulihkan. Berlainan dengan sebagian besar orang Belanda maupun orang Jawa yang mendapatkan pendidikan Barat, mereka percaya bahwa budaya Jawa kuno beserta sistem sosial yang berlaku dalam

12 Herman De Tollenaere, "Indian Thought In The Indies", dalam http: // www.iias.nl / iiasn /23/ theme / 23T2.html masa pra-kolonial masih memiliki peranan penting ketika Jawa memasuki zaman modern. Pada tahun 1918, Soewardi Soerjaningrat memuji Comite karena perjuangannya untuk revitalisasi budaya Jawa, meski demikian ia mengkritik sepupunya itu karena tujuan-tujuan politik Comite tidak jelas. Soeriokoesoemo membalas bahwa yang dimaksukannya adalah perkembangan nasion Jawa atau 'identitas Jawa' hanya dapat terwujud dalam suatu "negara yang didirikan oleh masyarakatmasyarakat Jawa" (Staat van Javaansche Gemeenschappen). Demikianlah tujuan dari Comite voor het Javaansche Nationalisme, yang kemudian dijadikan alasan bagi para pendukung nasionalisme Indonesia untuk menjauh dari kelompok ini (Miert, 2003: 128129).

Nasionalisme Jawa dan kampanye kebangkitan kembali budaya Jawa juga menarik perhatian sekelompok pelajar Jawa di Negeri Belanda. Salah satu tokoh yang terpenting adalah R.M. Noto Soeroto (18881951). Ia menamatkan HBS di Semarang pada tahun 1906, dan melanjutkan studi di Negeri Belanda untuk mempelajari hukum di Leiden. Antara tahun 1911 hingga 1914 ia menjabat sebagai ketua Indische Vereniging, perkumpulan pelajar Hindia di Negeri Belanda yang menjadi cikal bakal Perhimpunan Indonesia. Sebagai sastrawan, Noto Soeroto sangat kuat diilhami penyair-mistikus India, Rabindranath Tagore. Hampir setiap bulan ia menulis tulisan dalam "Wederopbouw", artikelartikel tentang kebangkitan kebudayaan Asia dan berbagai tulisan apresiasi tentang Tagore. Sepanjang hidupnya Noto Soeroto tetap konsisten menjadi pendukung politik asosiasi. Ia yakin bahwa hanya dengan memanfaatkan sebaik-baiknya politik Etis dan bekerjasama dengan kaum kolonial, orang Jawa dapat mencapai kemajuan. Sikap ini pada tahun 1920-an semakin tidak populer, sehingga pada Desember 1924, ia dikeluarkan dari Perhimpunan Indonesia - penerus Indische 
Vereniging setelah ia menulis tulisan bernada simpati kepada "pasifikator Aceh", J.B. Van Heutsz dalam majalah asosiasinya "Oedaya" (Miert, 2003: 124-125).

Gagasan Noto Soeroto tentang politik dapat dirumuskan dengan konsep "aristodemokrasi”, yang dipublikasikan dalam bukunya di tahun 1931. Ia menganjurkan adanya semacam dewan legislatif di tingkat kabupaten yang dipiilih secara tak langsung dan hanya berfungsi sebagai penasihat bagi bupati. Demokrasi yang diterapkan di Hindia menurutnya tidak seharusnya meniru Barat melainkan bersumber dari pandangan dunia Timur. "Kesalahan" dari kebanyakan orang yang menginginkan kemerdekaan penuh dari Belanda adalah bahwa mereka memakai konsep-konsep yang asing dalam kehidupan orang Timur, mereka juga terlalu dipengaruhi oleh kaum Marxis yang memakai dalih pertentangan kelas untuk menggerakkan masyarakat lapisan bawah. Ia menganjurkan semacam sistem kasta, dimana "semua orang dengan bahagia menerima posisi sosial dan peranannya, tanpa cemburu akan keistimewaan yang kebetulan dimiliki kelompok sosial lainnya" (Tollenaere, 1996: 358-359).

Sumber inspirasi lainnya dari nasionalisme dan gerakan revivalisme kultural Jawa berasal dari India, dimana kultus India memang sangat dipengaruhi oleh gerakan Teosofi. Ada dua orang tokoh yang sangat memberi pengaruh terhadap dunia pergerakan yaitu Rabidranath Tagore (1881-1941) dan Mohandas K. Gandhi (1869-1948). Dalam hal ini Tagore, teladan utama Noto Soeroto, adalah tokoh yang lebih banyak menginspirasi kalangan Teosof dan nasionalis Jawa. Soetatmo Soeriokoesoemo menyebut Tagore sebagai 'guru spiritual', dan Gandhi 'guru material' bagi masyarakat Hindu di India. Tagore merupakan 'suara Timur' yang sangat didengar oleh peradaban Barat. Sementara itu Gandhi, meski sempat sangat dipengaruhi Perkumpulan Teosofi kemudian menjadi sosok yang kurang populer di kalangan
Teosof, sejak ia berselisih paham dengan Annie Besant mengenai perlunya sikap non-kooperatif terhadap pemerintah. Soetatmo menganggap konsep perjuangan Gandhi, satyagraha atau non-kooperatif tidak terlalu efektif, jika bagaimanapun Inggris lebih mendengarkan suara-suara moderat seperti Tagore. Meski tetap menunjukkan ketidaksepakatan dengan kaum non-kooperatif, di depan Volksraad Soetatmo juga memperingatkan pemerintah bahwa keadaan di Hindia Belanda bukan tidak mungkin akan seperti di India. "Pada saat ini sudah cukup banyak yang tidak menginginkan kerjasama dengan pemerintahan asing. Karena itu jangan terlalu cepat bergembira jika kami tetap tinggal setia, karena dalam prinsip perwalian kolonial ada tanggung jawab moral kepada penduduk Hindia ini" (Tollenaere, 1996: 343-344).

Pemikiran-pemikiran kaum nasionalis Jawa yang didukung para Teosof semakin kurang populer sejak semakin kuatnya kelompok non-kooperatif dalam pergerakan. Aliran terakhir ini didukung oleh kaum Marxis dan kaum nasionalis pendukung kebangsaan Indonesia - penerus nasionalisme Hindia IP. Secara umum pengaruh gerakan Teosofi dalam politik memang menurun sejak mundurnya D. Van Hinloopen Labberton sebagai presiden NITV, untuk kemudian meninggalkan Hindia menuju Jepang pada Oktober 1923 (Nugraha, 2001: 46-47). Tidak ada alasan yang jelas mengenai latar belakang pengunduran diri Labberton kecuali bahwa ia hanya menyatakan ingin meneruskan dharma-nya di tempat lain. Meski demiikian dapat diduga bahwa mundurnya Labberton ada kaitannya dengan semakin tidak populer dan ditinggalkannya gagasan asosiasi dalam dunia pergerakan. 


\section{Kesimpulan}

Gerakan Teosofi di Indonesia masa kolonial merupakan bagian dari arus besar esoterisme Barat yang tengah melebarkan pengaruhnya ke belahan dunia Timur, sejalan dengan perkembangan kajian-kajian oriental dari kolonialisme Barat. Perkumpulan Teosofi adalah organisasi esoteris dengan tujuan untuk melestarikan kebijaksanaan abadi yang menjadi landasan baik kebenaran teologis-keagamaan maupun saintifik. Hal ini diungkapkan dalam The Secret Doctrine (1888), karya Helena Petrovna Blavatsky yang dianggap sebagai kitab gerakan Teosofi. Dalam perkembangannya Teosofi telah menjadi pusat intelektual bagi kajian perbandingan teologi dan okultisme, sekaligus sebagai gerakan kuasi-keagamaan dengan unsur millenarian. Di bawah kepemimpinan Annie Besant Teosofi juga menjadi wadah bagi aktivisme politik yang terkait dengan gerakan emansipasi nasionalis maupun sosialisme.

Kecenderungan ajaran Teosofi dalam mengadopsi konsep-konsep Timur dalam sistem esoterisme Barat, secara tak langsung mendorong renaisans budaya lokal seperti yang terjadi dengan gerakan nasionalisme Hindu di India maupun kebangkitan kembali budaya Jawa di kalangan kaum priyayi baru. Di Indonesia, berkembangnya kultus kebijaksanaan India kuno di kalangan Teosof telah ikut memperkuat sentimen para priyayi Jawa akan warisan Jawa-India mereka dari masa Majapahit. Jawa Kuno mulai dianggap sebagai gambaran masyarakat yang ideal sekaligus sebagai sumber kebijaksanaan yang tak lekang oleh waktu. Pada masa yang lebih belakangan, kita melihat bahwa para pemimpin nasionalis Indonesia - bahkan yang non-Jawa - ikut menjadikan Jawa kuno sebagai ikon nasionalisme Indonesia. Kampanye untuk kebangkitan kembali kebudayaan Jawa klasik ini telah didukung pula oleh kelompok orientalis Belanda, yang melihat bahwa penguatan identitas lokal tertentu perlu dilakukan demi mengantisipasi kelompok lain yang dianggap lebih berbahaya : gerakan kebangkitan politik Islam atau pan-Islamisme.

Gerakan Teosofi memiliki pengaruh terbesar pada periode awal pergerakan nasional, tepatnya pada tahun 1908 hingga 1926, suatu periode yang disebut juga sebagai zaman asosiasi. Pada masa ini kelompok Teosofi dibawah pimpinan Hinloopen Labberton menjadi pelopor dalam mewujudkan asosiasi di Hindia Belanda, khususnya dalam hubungannya dengan para tokoh pergerakan dari Boedi Oetomo (BO). Pengaruh gerakan Teosofi dan asosiasi pada dasarnya mencakup spektrum pemikiran politik yang cukup beragam. Meski demikian pada pengaruh Teosofi di kalangan nasionalis pada umumnya lebih dominan pada spektrum politik konservatif. Tokoh seperti Soetatmo Soeriokoesoemo misalnya, mendukung kemerdekaan Jawa dibawah pemerintahan otokrasi, mengikuti model raja-raja Jawa pra-kolonial. Sementara itu tokoh lainnya, R.M. Noto Soeroto, melihat bahwa Jawa sama sekali belum siap untuk kemerdekaan. Baginya kampanye asosiasi semestinya dimanfaat sebaik-baiknya sebagai medium bagi orang Jawa untuk lebih mengejar ketertinggalannya dari Barat, karena itu sistem yang paling ideal bagi Indonesia adalah negara persemakmuran di bawah naungan Kerajaan Belanda. Dengan pemikiran yang cenderung moderat dan konservatif, gerakan Teosofi Hindia dibawah Labberton ini semakin terkucil dari arus utama gerakan nasionalis Indonesia, khususnya pada dekade 1920-an. Bagi kalangan agama, khususnya Islam, sinkretisme Teosofi sejak awal telah dicurigai akan merusak akidah keagamaan. Sementara itu bagi kaum Marxiskomunis, gerakan Teosofi baik dengan aktivitas okultismenya maupun dengan gagasannya tentang asosiasi Barat dan Timur, lebih dianggap sebagai gerakan konservatif yang mendukung kepentingan pemerintah. 


\section{Daftar Pustaka}

Artawijaya, M (2010). Gerakan Theosofi di Indonesia: Menelusuri Jejak Aliran Kebatinan Yahudi Sejak Masa Hindia Belanda Hingga Era Reformasi. Jakarta: Pustaka Al-Kautsar.

Blavatsky, Helena Petrovna (1889). The Key to Theosophy, Theosophical University Press Onlne Edition

(1888), The Secret Doctrine : The Synthesis of Science Religion and Philosophy Vol 1 : Cosmogenesis, London : The Theosophical Publishing Company.

Clarke, J.J. (1997). Oriental Enlightenment : The Encounter Between Asian and Western Thought. New York : Routledge

Cote, Joost \& Westerbeek, Loes (ed). (2004). Recalling The Indies : Kebudayaan Kolonial dan Identitas Poskolonial, Yogyakarta : Syarikat

De Tollenaere, Herman A.O. (1996). The Politics of Divine Wisdom : Theosophy and Labour, National and Woman's movements in Indonesia and South Asia 1875-1947, Leiden : Katolieke Universiteit Nijmegen

Dixon, Joy (2001). Divine Feminine : Theosophy and Feminism in England, Baltimore / London : The John Hopkins University Press

Goodrick-Clarke, Nicholas (2008). The Western Esoteric Traditions : A Historical Introduction. New York : Oxford University Press (2005). The Occult Roots of Nazism : Secret Arian Cults and their influence on Nazi ideology, London / New York : Tauris Parke Paperbacks

Hanegraaff, Wouter J., et.al. (ed) (2006). Dictionary of Gnosis and Western Esotericism, Leiden : Koninklijke Brill NV.

Hanneman Samuel (2010). Genealogi Kekuasaan Ilmu-Ilmu Sosial Indonesia, Jakarta : Kepik Ungu.
Iskandar P. Nugraha (2001). Mengikis Batas Timur dan Barat : Gerakan Theosofi dan Nasionalisme Indonesia, Jakarta : Komunitas Bambu.

Jinarajadasa, C. (1957). Mula - Dasar Theosofi. Perhimpunan Theosofi Tjabang Indonesia.

Miert, Hans van (2003). Dengan Semangat Berkobar: Nasionalisme dan Gerakan Pemuda di Indonesia 1918-1930. Jakarta: KITLV/Hasta Mitra

Nagazumi, Akira (1989). Bangkitnya Nasionalisme Indonesia : Budi Utomo 1908-1918. Jakarta : Pustaka Sinar Harapan

Pradipto Niwandhono (2011). Yang Ter(di) lupakan: Kaum Indo dan Benih Nasionalisme Indonesia. Yogyakarta : Djaman Baroe

Said, Edward W. (2010). Orientalisme : Menggugat hegemoni Barat dan mendudukkan Timur sebagai subjek. Yogyakarta : Pustaka Pelajar

Savitri Prastiti Scherer (1985). Keselarasan dan Kejanggalan : Pemikiran-pemikiran Priyayi Nasionalis Jawa Awal Abad XX, Jakarta: Pustaka Sinar Harapan

Stevens, Th (2004). Tarekat Mason Bebas dan Masyarakat di Hindia Belanda dan Indonesia, 1764-1962, Jakarta : Pustaka Sinar Harapan Stuckrad, Kocku van (2005). Western Esotericism : A Brief History of Secret Knowledge, London : Equonox Publishing

Taylor, Jean Gelman (2009). Kehidupan Sosial di Batavia, Jakarta : Masup Jakarta / Komunitas Bambu.

\section{Sumber Internet}

Artawijaya, "Harkitnas dan Boedi Oetomo dalam Bayang-Bayang Freemason dan Theosofi", dalam http ://www.voa-islam.com//

Herman De Tollenaere, "Indian Thought In The Indies", dalam http: // www.iias.nl / iiasn /23/ theme / 23T2.html 
Susiyanto \& Fathurrahman Kamal, "Dari Theosofi menuju Pluralisme Agama, dalam M. Amin Rais, M. Syukriyanto, dkk. "1 Abad Muhammadiyah: Istiqomah Membendung Kristenisasi dan Liberalisasi”, diterbitkan oleh Majlis Tabligh dan Dakwah Khusus
Pimpinan Pusat Muhammadiyah dalam rangka Muktamar 1 Abad Muhammadiyah 3-8 Juli 2010 di Yogyakarta (http / / : www. muslimdaily.net)

Tedi Kholiludin, "Teosofi sebagai quasi agama", (http//: www.elsaonline.com) 